\title{
Torque improvement of PM motor with semi-cycle stator design using 2D-finite element analysis
}

\author{
Kwang T. C., Mohd Luqman Mohd Jamil, Auzani Jidin \\ Power Electronics and Drive Research Group (PEDG), Universiti Teknikal Malaysia Melaka, Malaysia
}

\begin{tabular}{l} 
Article Info \\
\hline Article history: \\
Received Apr 4, 2019 \\
Revised Jun 27, 2019 \\
Accepted Jul 7, 2019 \\
\hline
\end{tabular}

\section{Keywords:}

Overall weight

PM motor

Semi-circle stator

Torque density

\begin{abstract}
This paper presents sizing approaches to improve output torque performance in PM motor when partial stator body is removed. As the output torque performance is directly proportional to the electric loading, Q, modification on stator geometry affects the output torque performance and special procedures have to be taken to restore the desired output torque capability. Influences of split ratio, tooth body width, airgap and magnet thickness of magnet in PM motor with asymmetry stator design are carried out and the performance verification are referred to the back-emf, average output torque, torque ripple as well as cogging torque. From the investigation using 2D-Finite Element Analysis, optimum size of tooth body width and optimum number of coil turns result better output torque while other sizing approaches result no significant change as quick saturation took place.
\end{abstract}

Copyright (C) 2019 Institute of Advanced Engineering and Science. All rights reserved.

\section{Corresponding Author:}

Mohd Luqman Mohd Jamil,

Power Electronics and Drives Research Group (PEDG),

Universiti Teknikal Malaysia Melaka,

Hang Tuah Jaya, 76100 Durian Tunggal, Melaka, Malaysia.

Email: luqman@utem.edu.my

\section{INTRODUCTION}

Permanent magnet (PM) brushless motors are favorable in industries due to simple construction led to light-weight, reliability, high efficiency, high torque density as well lesser noise generation [1-5]. According to back-emf profile, PM motors are commonly categorized into two operating modes, BLDC and BLAC, where the BLDC mode may offer high efficiency and high output torque performance as compared to the BLAC mode for a given design [6]. Conventionally, BLDC motors with radial flux orientation and equipped with Neodymium Iron Boron $(\mathrm{NdFeB})$ permanent magnet on rotor results superior electromagnetic characteristics at on-load and having robust performance [7-9]. However, unoptimized design parameters may cause performance degradation i.e low power-to-weight ratio, low efficiency, low torque density but having bulky size. For an average torque improvement, various topologies related to geometry modification such as having hollow iron rotor, slimmer tooth body width and back iron width for a high number of coil turns, smaller and asymmetric air gap [10-12]. On rotor design side, pole embrace, shape of magnet, magnet skew and type of magnetization i.e parallel and hallbach were among popular steps to enhance output average torque [13-15]. By having proper magnet geometry and parallel magnetization, a decentred magnet rotor results a relative high of flux density, average torque and efficiency [16]. For a limited motor volume, determination of split-ratio also enhances electromagnetic torque capability although magnetic and electric loadings are crucial in the first place [17]. According to [18], optimization of magnet fraction, slot opening, airgap length, tooth body width, magnet thickness and number of coil turns result significant improvement in torque performance. A determination of specific airgap thickness should not be ignored as it provides a correlation between the motor torque performance and cost. 
In this article, further investigation on the developed prototype as in $[19,20]$ is carried out using by 2-D Finite-Element Analysis. Influences of split ratio, stator tooth body width, airgap thickness and magnet thickness respectively are included. The initial motor design with hemicycle stator and conventional SPM rotor was aimed to reduce overall motor weight without sacrificing overall torque performance.

\section{ANALYSIS OF PARAMETRIC DESIGNS}

Due to symmetric 3-phase winding mmf vectors, motor with slot number, $\mathrm{N}_{\mathrm{s}}$ is even is the best choice as compared the motor with $\mathrm{N}_{\mathrm{s}}$ is odd. The remaining part of stator body still can give a balanced mmf vectors with $120^{\circ}$ phase displacement as all three phases windings are still visible as shown in Figure $1 \mathrm{~b}$. The dash lines represent set of coils that has been removed as semi-cycle stator design is implemented. While for odd slot number, the mmf vectors are not balanced as almost only one phase left.

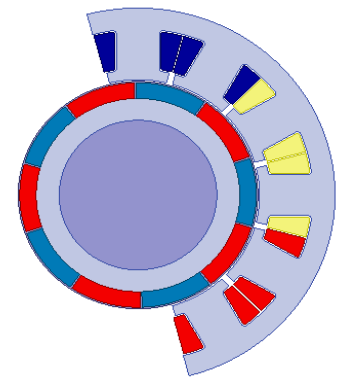

(a.1). $N_{s}=$ even (Design 1, 12-slot)

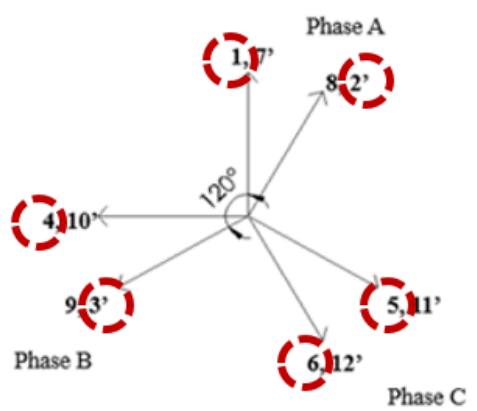

(b.1). Ns = even $($ Design 1$)$

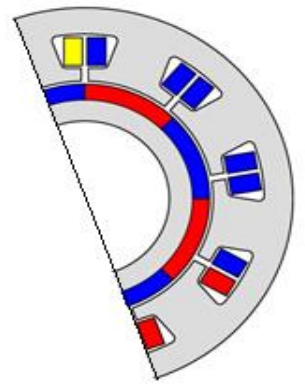

(a.2). $N_{s}=$ odd $(9-$ slot $)$

(a)

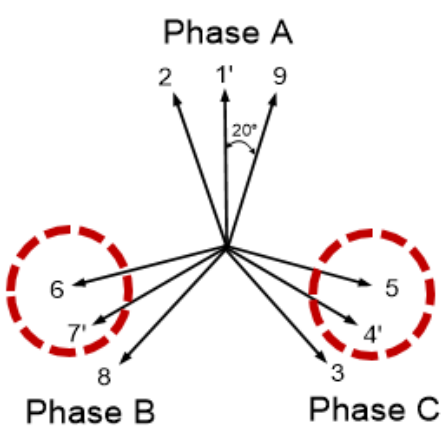

(b.2). Ns = odd

(b)

Figure 1. Even $N_{s}$ vs odd $N_{s}$, (a) Design layouts, (b) Mmf vectors

\subsection{Split Ratio}

In motor design perspective, electromagnetic torque performance is directly proportional to the square of motor diameter, D2, axial length, La, electrical loading, Q and magnetic loading, B. For an optimum torque performance, a good compromise between the stator outer diameter, D and the motor axial length of motor is needed. However high quantity product of electric and magnetic loadings is a must when big sizing becomes a main constraint in order to achieve high torque and high power density. In many cases where limitations on slot fill factor, slot depth, thermal factor and coil current density exist, a relative low of electric loading is unavoided. In other way, a specific maximum flux distribution (leading to a limited quantity of magnetic loading) between the rotor surface and stator teeth is needed to avoid high saturation condition. With a high electric and magnetic loadings, a higher number of copper turns may also affect the split ratio as high electromagnetic performance is dominated by the electric and magnetic loadings respectively. Table 1 tabulates the parametric specification of Design 1 over different split ratios. The phase current of 10 A remains in all conditions. A relation between the stator inner diameter, D to stator outer diameter, Ds is expressed as (1). 


$$
\gamma=\frac{D}{D s}
$$

Table 1. Parametric specifications over split ratios

\begin{tabular}{cccccc}
\hline Parameter & \multicolumn{5}{c}{ Specifications } \\
\hline Split ratio & 0.5 & 0.55 & 0.6 & 0.65 & 0.7 \\
Stator outer diameter (mm) & & & 120 & & \\
Stator inner diameter (mm) & 60 & 66 & 72 & 78 & 82 \\
Tooth body width (mm) & 11.5 & 12.4 & 13.1 & 13.4 & 14.2 \\
Stator back iron (mm) & 5.3 & 5.6 & 6.7 & 6.6 & 5.6 \\
Slot depth (mm) & 21 & 17.4 & 13 & 10.3 & 9.4 \\
Number of coil turns & 130 & 118 & 104 & 89 & 74 \\
Axial length (mm) & & & 20 & & \\
Magnet thickness (mm) & & & 5 & & \\
Airgap length (mm) & & & 1.1 & \\
Slot opening (mm) & & 3.3 & \\
Tooth tip thickness (mm) & &
\end{tabular}

\subsection{Tooth body width}

For a given motor size, number of coil turns in each stator slots is influenced by the slot fill area. A specific slot area tends to limit the number of coil turns as it also depends on the availability from standard manufacturing. As the spirit for high electric loading, the dimension of stator tooth body width in Design 1 is investigated. In earlier design, the motor design with split ratio 0.6 and tooth body width of 13 . $1 \mathrm{~mm}$ is investigated. By referring to Table 2, for an optimum number of coil turns, the tooth body reduces gradually and results bigger slot area and higher number of coil turns in the stator slots. The total area conductor per slot is calculated for given specific stator tooth body width where the saturation effect is ignored. While other motor dimension is maintained. All design is then re-analysed by using 2D-Finite Element Analysis by taking into account the saturation condition.

Table 2. Influence of tooth body width on number of coil turns

\begin{tabular}{cccccc}
\hline Parameter & \multicolumn{5}{c}{ Specifications } \\
\hline Tooth body width $(\mathrm{mm})$ & 9.1 & 10.1 & 11.1 & 12.1 & 13.1 \\
Number of coil turns & 152 & 144 & 136 & 138 & 104 \\
\hline
\end{tabular}

\subsection{Airgap thickness}

The airgap thickness between stator and rotor may varies according to the motor size. An optimum airgap size may result high airgap flux density, a relative low cogging torque and high torque performance. As the airgap becomes narrow, the motor results high value of phase inductance and offers high output torque. However, high cogging torque and severe in vibration are the drawbacks for the smaller airgap dimension if slot-opening size remains unchanged. With the spirit to achieve high output torque and low cogging torque, the airgap thickness is investigated by varying from $0.5 \mathrm{~mm}$ to $1 \mathrm{~mm}$ in Design 1 .

\subsection{Magnet thickness}

In radial flux motor, the NdFeB permanent magnet has gain popularity due to high coercivity and high remanence [21] characteristics. The $\mathrm{NdFeB} P M$ parallelly magnetized is mounted with unity pole embrace on rotor surface. For high magnetic flux density, an optimum magnet thickness should be properly calculated to avoid potential of severe saturation that inherently limits the output torque. As magnet thickness increases, the motor results high flux density and high electromagnetic torque. An investigation is carried out with a variation from $5 \mathrm{~mm}$ to $8 \mathrm{~mm}$ while other motor parameters remain unchanged.

\section{RESULTS AND ANALYSIS}

\subsection{Split ratio}

Phase back-emf of all designs are shown in Figure 2(a) where the prediction is obtained at $100 \mathrm{rpm}$ rated speed. The peak back-emf for original Design $1(\gamma=0.6)$ is $3.2 \mathrm{~V}$. As the split ratio becomes bigger, the peak phase back-emf is theoretically reduced due to small stator slot area and number of coil turns. For split ratio 0.7 in Design 1, the peak back-emf reduces $18 \%$ from the initial design to 2.6V. All design 
indicate a trapezoidal current is a better candidate than sinusoidal excitation current for a constant electromagnetic torque. Based to Figure 2(b), the rise of multiple harmonic order i.e. $3^{\text {rd }}$ and $5^{\text {th }}$ depicts dented peaks and non-sinusoidal profile.

Comparisons of cogging torque and average output torque over various split ratios are shown in Figure 3. For cogging torque as in Figure 3(a), there are only two cycles exist over $360^{\circ}$ electrical degrees instead of 12 cycles for the previous original design. It can be seen that the original Design 1 has a peak-topeak cogging torque of $1.0 \mathrm{Nm}$. The peak of cogging torque increases when the split-ratio increases and the higher the cogging torque may cause higher torque ripple and unwanted vibration exist.

For the torque performance as in Figure 3(b), the average output torque tends to be lower while having high torque ripple especially when split-ratio increases beyond 0.6. The Design 1 results an average torque of $4.8 \mathrm{Nm}$ and $60 \%$ torque ripple for a split-ratio of 0.6 .

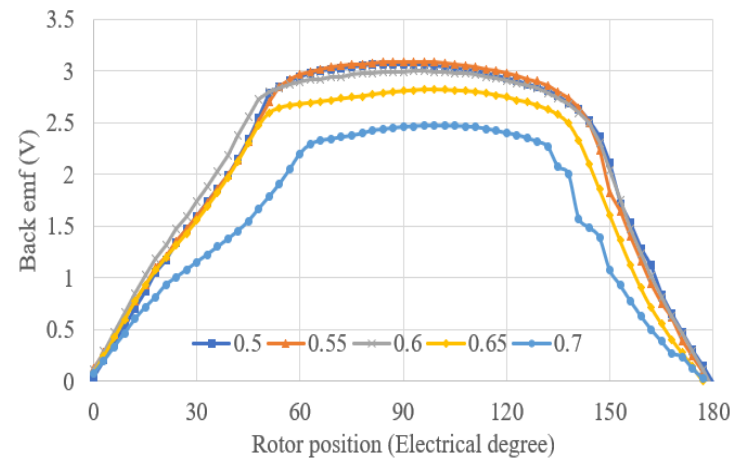

(a)

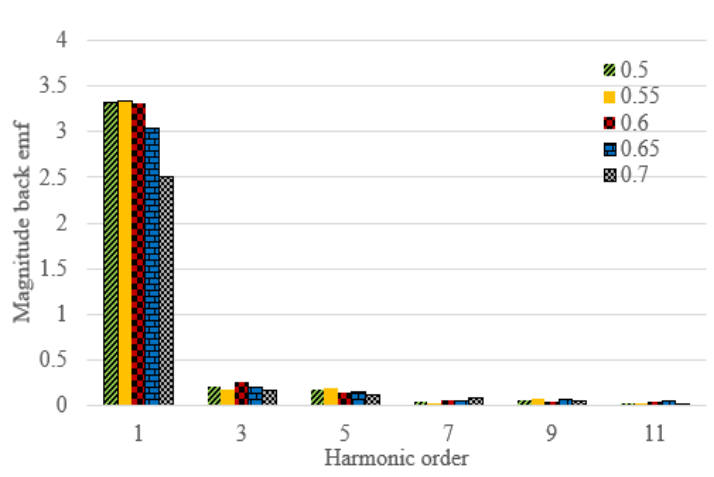

(b)

Figure 2. Back-emf, (a) Phase back-emf, (b) Harmonics components

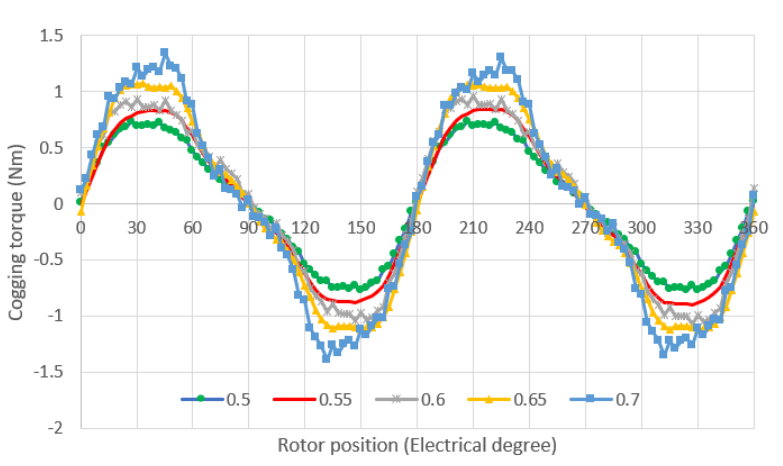

(b)

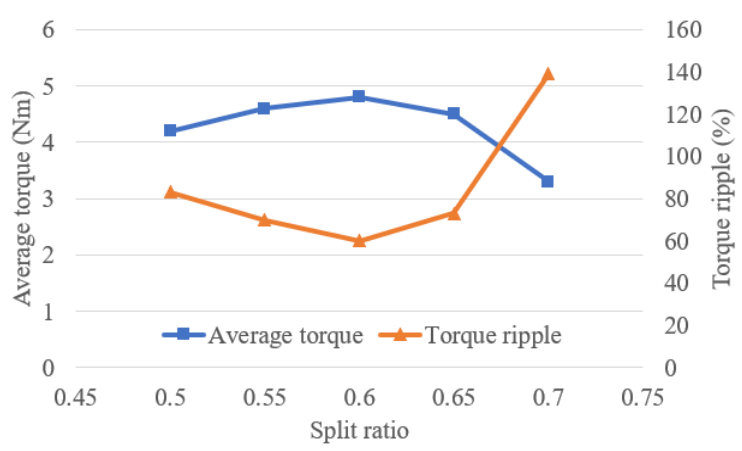

(a)

Figure 3. Cogging torque and output torque, (a) Cogging torque, (b) Average torque and ripple

\subsection{Tooth Body Width}

Figures 4(a) depicts the peak phase back-emf of all designs over various width of stator tooth body. When the stator tooth body width changes to $9.1 \mathrm{~mm}$, the peak $3 \mathrm{~V}$ of the original Design 1 is then increased by $43 \%$ resulting $4.3 \mathrm{~V}$. The motor is capable to have larger slot area and higher number of coil turns if thinner tooth body width is considered, but this will cause the motor saturable easily due to high quantity of electric loading. A quasi-phase current is a better choice as the back-emf profile closer to the trapezoidal form instead of sinusoid. According to Figure 4(b), smaller stator tooth body width i.e $9.1 \mathrm{~mm}$ result highest fundamental component and indicates dented peaks as the rise of higher multiple order harmonics. For cogging torque, it is found that there is no significant achievement when tooth body width is varied. Generally, low cogging torque may cause low ripple on output torque except there is mismatch between back-emf and excitation current during commutation.

Static torque performance of all designs where the motors are excited with trapezoidal phase current of $10 \mathrm{~A}$ are shown in Figure 5(b). For the original Design 1, an average torque of $4.8 \mathrm{Nm}$ and $60 \%$ torque ripple are obtained. A higher average torque is obtained when higher coil turns is occupied as the tooth body

Torque improvement of PM motor with semi-cycle stator design using $2 D$-finite element... (Kwang T. C) 
width getting thinner but unwanted quick saturation may appears. For a given tooth body width of $11.1 \mathrm{~mm}$, the motor results an increase of average torque by $19 \%$, equivalent to $5.7 \mathrm{Nm}$ but with $55.6 \%$ torque ripple too. Theoretically, care should be taken during excitation to avoid quick saturation exists.

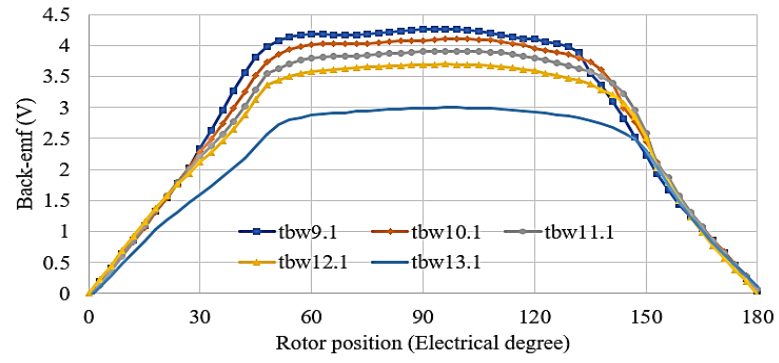

(a)

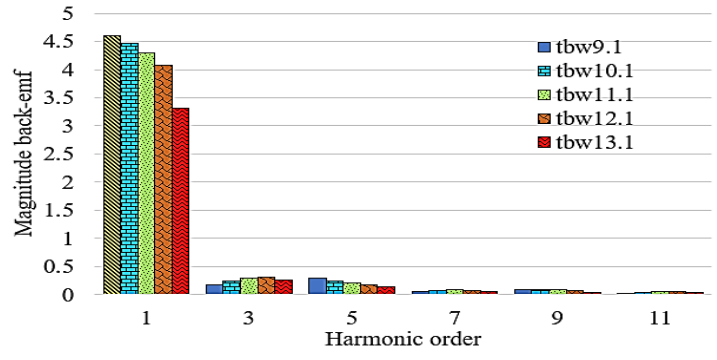

(b)

Figure 4. Back-emf, (a) Phase back-emfs, (b) Harmonics components

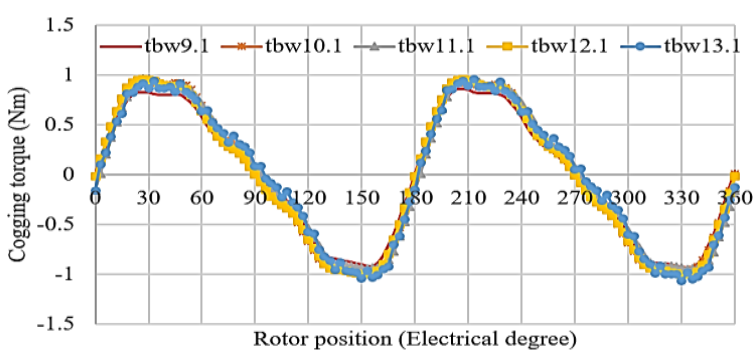

(a)

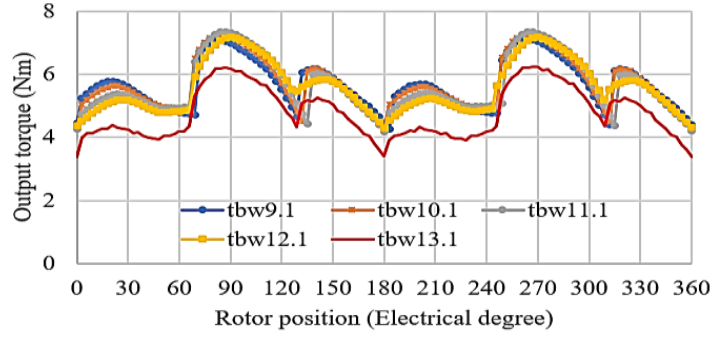

(b)

Figure 5. Cogging torque and output torque, (a) Cogging torque, (b) Static torque

\subsection{Airgap Thickness}

The influence of airgap thickness on the proposed design are shown in Figures $6-7$. In general, the bigger the airgap, the smaller back-emf is obtained. However, the situation reverse as shown in Figure 6(a). For an airgap of $0.5 \mathrm{~mm}$, the peak of back-emf increases up to $11 \%$ resulting $3.34 \mathrm{~V}$ as compared to the actual design. According to Figure $6(\mathrm{~b})$, the $0.5 \mathrm{~mm}$ airgap results a superior fundamental component back-emf. All design shows dented peaks as higher multiple order harmonics exists. Similar to Figure 5(a), the cogging torque in Figure 7(a) results no significant change in peak-to-peak magnitude. As airgap dimension become narrow, the peak cogging torque increases resulting higher torque ripple and unwanted vibration in asymmetry motor design. In term of output torque performance as in Figure 7(b), the average torque and torque ripple are relatively constant and the $0.5 \mathrm{~mm}$ airgap is still the best choice.

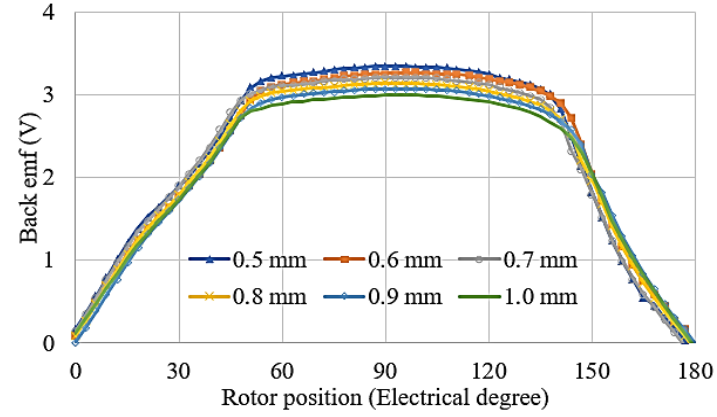

(a)

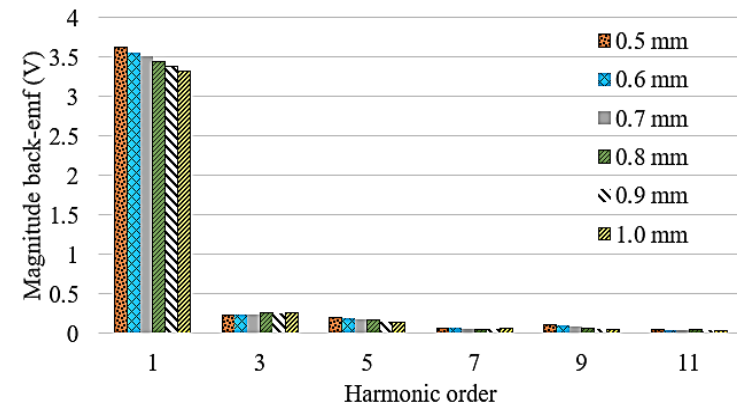

(b)

Figure 6. Back-emf analysis, (a) Phase back-emfs, (b) Harmonics components 


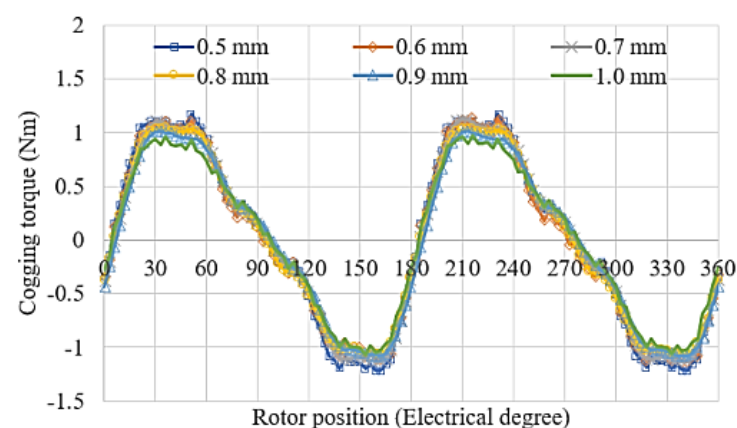

(a)

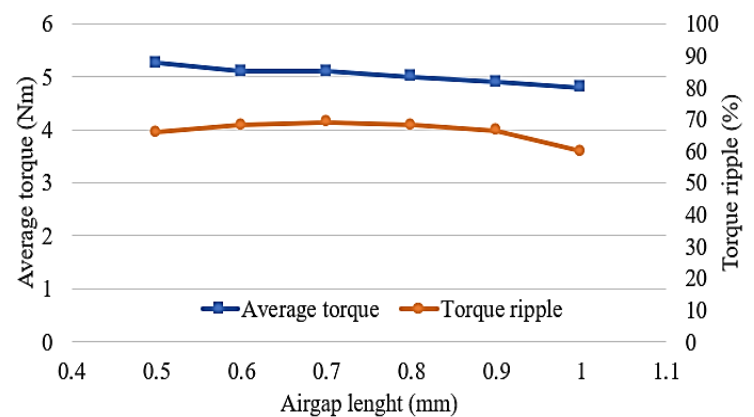

(b)

Figure 7. Electromagnetic torque analysis, (a) Cogging torque, (b) Average torque and ripple

\subsection{Magnet Thickness}

It is found that the influence of magnet thickness is relatively similar to the influence of airgap thickness. As shown in Figure 8, the Design 1 is initially equipped with $5 \mathrm{~mm}$ magnet thickness where the peak back-emf is $3.0 \mathrm{~V}$. For a magnet thickness of $8 \mathrm{~mm}$, the peak back-emf increases by $4 \%$ resulting $3.12 \mathrm{~V}$. The influence of magnetic loading, B due to magnet volumes results higher magnetic interaction between magnet and slot permeance, this can be seen in Figure 9(a) where all bigger thickness of magnet results higher cogging torque. For example, the Design 1 that cogging torque of $0.9 \mathrm{Nm}$ experiences a slight increase of cogging torque as $1.2 \mathrm{Nm}$ when magnet thickness is $8 \mathrm{~mm}$.

In term of output torque performance as in Figure 9(b), the average torque is relatively constant while the torque ripple gradually increases. In the earlier standard design, the motor developed an average torque of $4.8 \mathrm{Nm}$ and $60 \%$ torque ripple. As magnet thickness increases to $7 \mathrm{~mm}$, quick saturation occurs and limits the average torque increment up to $4 \%$ only. It is found that the $5 \mathrm{~mm}$ magnet thickness remains as the best size.

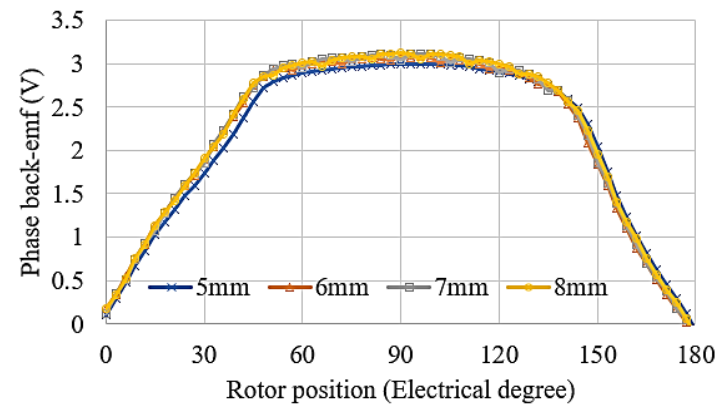

(a)

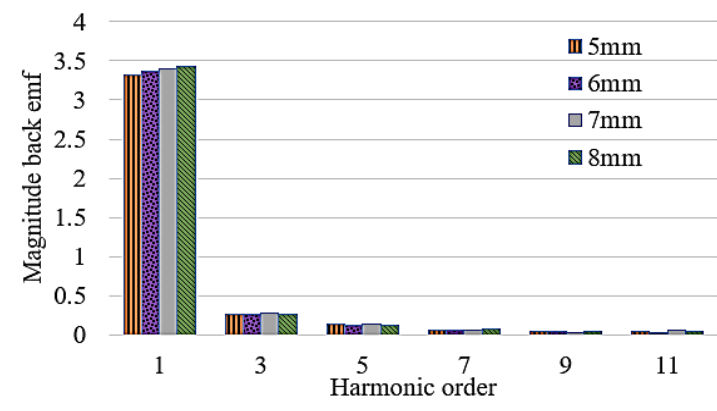

(b)

Figure 8. Back-emf analysis, (a) Phase back-emfs, (b) Harmonics components

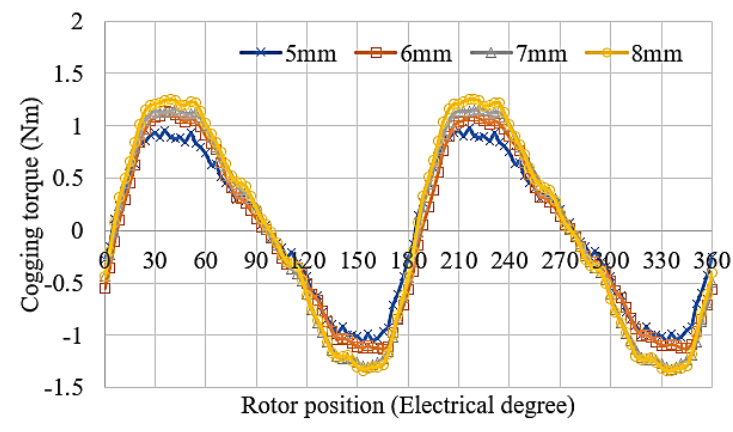

(a)

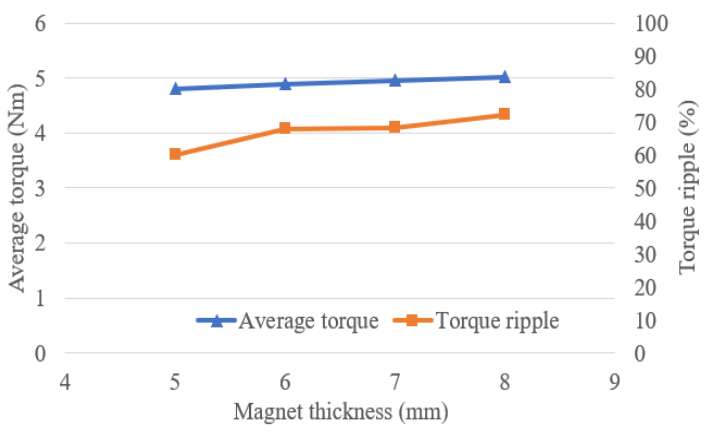

(b)

Figure 9. Electromagnetic torque analysis, (a) Cogging torque, (b) Average torque and ripple 
Table 3 tabulates predicted results of back-emf, cogging torque, average output torque and torque ripple over selected sizing parameters. It comfirms that only sizing of tooth body width in Design 1 results significant improvement as the phase back-emf boosted up to $42 \%$ while the average output torque inreases up to $19 \%$.

Table 3. Proposed method on variation parameters

\begin{tabular}{|c|c|c|c|c|c|c|}
\hline & Sizing parameter & Parameter & $\begin{array}{l}\text { Peak back- } \\
\text { emf (V) }\end{array}$ & $\begin{array}{l}\text { Peak cogging } \\
\text { torque }(\mathrm{Nm})\end{array}$ & $\begin{array}{c}\text { Average } \\
\text { torque }(\mathrm{Nm})\end{array}$ & $\begin{array}{c}\text { Torque } \\
\text { ripple (\%) }\end{array}$ \\
\hline \multirow[t]{5}{*}{1} & Split ratio & 0.5 & 3.28 & 0.73 & 4.2 & 83.0 \\
\hline & & 0.55 & 3.27 & 0.85 & 4.6 & 70.0 \\
\hline & & 0.6 & 3.16 & 0.96 & 4.8 & 60.0 \\
\hline & & 0.65 & 2.93 & 1.07 & 4.5 & 73.0 \\
\hline & & 0.7 & 2.56 & 1.34 & 3.3 & 139.0 \\
\hline \multirow[t]{5}{*}{2} & Tooth body width (mm) & 9.1 & 4.27 & 0.86 & 5.7 & 51.8 \\
\hline & & 10.1 & 4.10 & 0.93 & 5.7 & 52.3 \\
\hline & & 11.1 & 3.91 & 0.96 & 5.7 & 55.6 \\
\hline & & 12.1 & 3.70 & 0.96 & 5.6 & 58.3 \\
\hline & & 13.1 & 3.00 & 0.96 & 4.8 & 60.0 \\
\hline \multirow[t]{6}{*}{3} & Airgap (mm) & 0.5 & 3.34 & 1.17 & 5.3 & 68.8 \\
\hline & & 0.6 & 3.27 & 1.13 & 5.1 & 68.5 \\
\hline & & 0.7 & 3.21 & 1.10 & 5.0 & 67.2 \\
\hline & & 0.8 & 3.14 & 1.04 & 4.9 & 66.3 \\
\hline & & 0.9 & 3.07 & 1.02 & 4.9 & 64.8 \\
\hline & & 1.0 & 3.00 & 0.96 & 4.8 & 60.0 \\
\hline \multirow[t]{4}{*}{4} & Magnet thickness (mm) & 5 & 3.00 & 0.96 & 4.8 & 60.0 \\
\hline & & 6 & 3.08 & 1.14 & 4.9 & 68.0 \\
\hline & & 7 & 3.11 & 1.17 & 5.0 & 68.3 \\
\hline & & 8 & 3.12 & 1.26 & 5.0 & 72.3 \\
\hline
\end{tabular}

\section{CONCLUSION}

From the investigation, the PM motor equipped with semi-circle stator design can have better electromagnetic performance via optimum size of tooth body width and coil turns respectively. A reduction of overall volume size can be achieved but performance degradation is unavoided. The proposed sizing parameters results improvement on the phase back-emf and average output torque performance but there is no significant reduction of output torque ripple.

\section{ACKNOWLEDGEMENTS}

The authors would like to thank Universiti Teknikal Malaysia Melaka (UTeM) for providing UTeM Zamalah Scheme, UTeM.29.02/600-1/9/5 Jld.6 for this research.

\section{REFERENCES}

[1] Manoj et al, "FEA of a High Efficiency Brushless DC Motor Design," International Journal of Applied Engineering Research, vol. 12(1), pp. 11417-11423, 2017.

[2] Shivraj \& Archana, "Mathematical Modelling and Simulation of Three Phase BLDC Motor Using MATLAB," International Journal of Advance in Engineering \& Technology, pp. 1426-1433, 2014.

[3] Yang M. et al, "A Cost-Effective Method of Electric Brake with Energy Regeneration for Electric Vehicle," IEEE Transaction on Industrial Electronics, vol. 56(6), pp. 2203-2212, 2009.

[4] Shirish \& Jain, "Modelling and Simulation of Three Phase BLDC Motor for Electric Braking Using MATLAB/ SIMULINK," vol. 5(1), pp. 48-53, 2017.

[5] Sanadhya N. et al, "Reliability of Permanent Magnet Brushless DC Drives using IGBT's," International Journal of Innovative Research in Science, Engineering and Technology, vol. 2(3), pp. 772-780, 2013.

[6] Masataka M. \& Kan A., "Efficiency Comparison between brushless DC Motor and Brushless AC Motor Considering Driving Method and Machine Design," IEEJ Journal of Industry Application, vol. 2(1), pp. 79-86, 2012.

[7] G R. Puttalakshmi \& S. Paramasivam, "Electromagnetic Flux Analysis of Permanent Magnet Brushless DC Motor using Magnet Software," International Journal of Engineering and Technology, vol. 5(1), pp. 3215-3222, 2013.

[8] Indirajith K. \& Kumar R. B., "Comparative Study of The Transverse, Axial and Radial PM Synchronous Motors for Wind Application," International Journal of Electrical and Electronics Engineers, vol. 9(1), pp. 944-955, 2017.

[9] Chen A. et al., "Performance Comparisons Among Radial Flux, Multi-stage Axial Flux and Three-phase Transverse Flux PM Machines for Downhole Application," IEEE International Electric Machines and Drives Conference, 3-4 May 2009. 
[10] R. N. Firdaus et. al. "Design of Hollow-Rotor Brushless DC Motor," International Journal of Power Electronics and Drive System (IJPEDS), vol. 7(2), pp. 387-396, 2016.

[11] Seung-Han Kam \& Tae-Uk Jung, "A Design Optimization of Asymmetric Air-gap Structure for Small 3-phase Permanent Magnet SPM BLDC Motor,” Journal of Magnetics, vol. 20(1), pp. 91-96, 2015.

[12] Peter S. et al., "Characterization and Optimization of a Permanent Magnet Synchronous Machine," The International Journal for Computation and Mathematics in Electrical and Electronic Engineering, vol. 28(2), pp. 272-285, 2009.

[13] Han-Bit Kang, et. al., "Comparative Study of Torque Analysis for Synchronous Permanent Magnet Coupling with Parallel and Halbach Magnetized Magnets Based on Analytical Field Calculations," IEEE TRANSACTIONS ON MAGNETICS, vol. 50(11), pp. 1-4. 2014.

[14] Wenliang Z. et al., "Material-Efficient Permanent-Magnet Shape for Torque Pulsation Minimization in SPM Motors for Automotive Applications," IEEE TRANSACTIONS ON INDUSTRIAL ELECTRONICS, vol. 61(10), 5779-5787, 2014.

[15] M. Pourjafari, E. Fallah Choolabi \& M. Jafarboland, "Optimum Design of Brush- Less DC Motor with Minimum Torque Pulsation Using FEM\& PSO'," Amirkabir International Journal of Science\& Research (Electrical \& Electronics Engineering), vol. 4(2); pp. 59-70, 2012.

[16] W. Purwanto, "Design and Comparison of Five Topologies Rotor Permanent Magnet Synchronous Motor for High Speed Spindle Application," International Journal of GEOMATE, vol. 13(40), pp. 148-154, 2017.

[17] Li, Q., Dou, M., \& Fang, C., "Analytical Determination of Optimal Split Ratio for High-speed Permanent Magnet Brushless Motors," 2015 18th International Conference on Electrical Machines and Systems (ICEMS), Oct 25-25, 2015, Pattaya City, Thailand.

[18] Yee-Pien Yang, "Optimal Design and Control of a Torque Motor for Machine Tools," J. Electromagnetic Analysis \& Applications, vol. 1, pp. 220-228, 2009.

[19] Zolkapli Z. Z. et al, "Torque Ripple Minimization Technique in Fractional-slot PM Brushless Machines," 2014 IEEE Conference on Energy Conversion (CENCON), 13-14 October 2014. IEEE Publisher.

[20] M. Luqman, Kwang T. C. \& Auzani J., "Design and Analysis of PM motor with Semi-circle Stator Design using 2D-Finite Element Analysis," Indonesian Journal of Electrical Engineering and Computer Science, vol. 13(1), 427-436, 2019.

[21] M. Nicole et al., "Brushless DC Micro Motor with Surface Mounted Permanent Magnet," J. of Revue Roumaine des Sciences Techniques, vol. 3, pp. 237-247, 2014.

\section{BIOGRAPHIES OF AUTHORS}

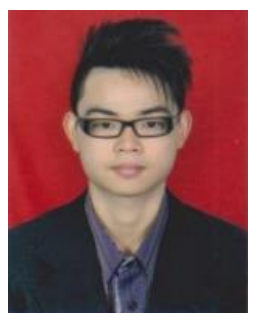

Tan Cheng Kwang was born in Kelantan, Malaysia in 1994 and received the B. Eng degree in Electrical from Universiti Teknikal Malaysia Melaka Malaysia (UTeM) in 2018. He is currently pursuing his Master of Science at Universiti Teknikal Malaysia Melaka, Malaysia.

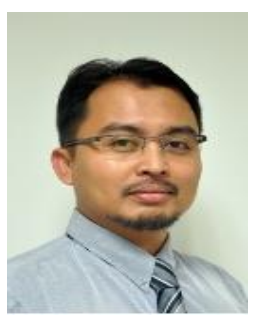

Mohd Luqman Mohd Jamil received the B.Eng. degree from the Universiti Teknologi MARA, Shah Alam, Malaysia, in 2000, the M.Sc. degree from Newcastle University, Newcastle upon Tyne, U.K., in 2003, and the Ph.D. degree from The University of Sheffield, Sheffield, U.K., in 2011, all in electrical engineering. He is currently an academician with the Department of Power Electronics and Drives, Faculty of Electrical Engineering, University Teknikal Malaysia Melaka, Melaka, Malaysia. His research interests include the design and analysis of permanent-magnet brushless machines.

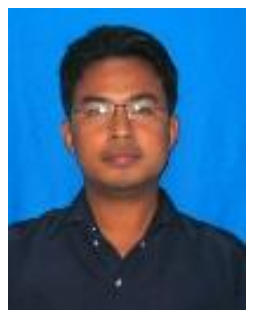

Auzani Jidin received his B. Eng, M. Eng. And Ph.D, in Power Electronics and Drives from Universiti Teknologi Malaysia (UTM), Johor, Malaysia in 2002, 2004 and 2011 respectively. He is an academician in Department of Power Electronics and Drives, Faculty of Electrical Engineering, Universiti Teknikal Malaysia Melaka Malaysia. His research interest includes the field of power electronics, motor drives systems, field programble gate arrays and digital signal processing applications. 